\title{
Experimentation of Brain Based Learning Model Based on Lesson Study Learning Community Towards Students' Reasoning Ability on Sequences and Series Material
}

\author{
Hobri ${ }^{1, *}$ Ervin Oktavianingtyas ${ }^{1}$ D Trapsilasiwi ${ }^{1}$ Randi Murtikusuma ${ }^{1}$ Didik \\ Pambudi ${ }^{1}$ Noor Amalia ${ }^{1}$
}

\author{
${ }^{1}$ Faculty of Teacher Training and Education, Jember University \\ Email: aannisa125@gmail.com
}

\begin{abstract}
The purpose of this research is to know How to process of teaching learning using Brain Based Learning which based on Lesson Study Learning Community as well the effect on students' reasoning abilities on the material sequences and number series at SMAN 5 Jember. The kind experiment that is used is mixed methods or methods that combine quantitative and qualitative methods, which refer to knowing whether there is an effect of students' reasoning abilities. The experiment of this research is Quasi Experiment the population being experiment is the students of XI MIPA, then a sample was taken so that XI MIPA 1 was the experimental class and class XI MIPA 2 was the control class. The techniques collection data is used are test, observation, and interview. The result of $t$ independent shows $\mathrm{T}_{\text {table }}<$ $\mathrm{T}_{\text {value, with }} \mathrm{T}_{\text {value }}=3.204$ and $\mathrm{T}_{\text {table }}=2.000$, so that when $\mathrm{H}_{0}$ is refused $\mathrm{H}_{1}$ is accepted. It is proved that the positive influence from Brain Based Learning applied based on Lesson Study Learning Community with the capability of students' reasoning skills on sequence and series materials.
\end{abstract}

Keywords: Brain Based Learning, Lesson Study Learning Community, Reasoning Ability.

\section{INTRODUCTION}

Learning is about being help to construct what the student's mean for themselves not for getting a correct answers because of the students are doing this, they are trained just for getting the correct answer and they are not really understand about the concept. Mathematics is not only limited to counting but to sharpen thinking skills. The ability to think includes the ability of problem solving, reasoning and proof, connections, communication, and representation[1]. The students capability of reasoning is one of the important element which is needed in Teaching Learning process especially in Mathematic lesson or subject, so the teacher hopefully able to arrange and plans the teaching learning process to develop the reasoning's capability of the students[2]. Reasoning is the capability which must be owed individually in making conclusion on what they have done[3]. Six aspects of mathematical thinking were taken i.e. Generalization, logical thinking, deduction, problem solving, induction and proofs[4]. While there some indicators of Reasoning Mathematically in this research[5] : (1) Able to solve the problem logically (logical thinking and problem solving). (2) Able to make explanations of model, picture, facts, correlation or pattern in deduction. (3) Able to analize the pattern to drawing the next information and make the coclusion generalization. The stlye of learning of the students are affected in reasoning capability such as Converger style. It has capability in solving problem and make conclusion. While Diverger that identified some chances in reality. The fact is there are many result of researches showed that most of the students used Deductive method in solving their problem in Math and the others[6]. The usage of Brain Based Learning which has intergrated ELT are able to combine the different style of learning every student's style which is researched because basically every human being has different style in learning which cannot be predicted in a short time[7]. 
In carrying out Mathematic successfully, it needed an application method of learning properly. One of it is Brain Based Learning (BBL), Brain Based Learning is a model of learning which is an environment of studying in or out of school, when the brain has it's function and it's take a part in learning used[8]. In Brain Based Learning there are some step should be done, they are [9] : (1) Pre Description (2) Preparation (3) Iniciation and Acquatition (4) Eleboration (5) Incubation and Posting Memory (6) Verification and Checking Desire (7) Celebration and Intergration. The function of Brain Based Learning can give acknowledge for teachers, material developer, and author tend to use the strategy of Brain Based Learning because it can help the students learn their lesson more effectively and the teaching learning process will be running well and success and enjoyable. Furthermore it can make the students more active, smart, and enjoy the process of learning and build their achievement and retention [10][11]. Related to the Brain Based Learning environment, students have stated that content has been presented in a meaningful whole and that they have a rich learning life organized. In this case since they can effective communication, sensitivity on individual differences, democratic attitude, active participation to the lesson, continuously of the lesson and the variety approach in evalvation have been determined as the positive aspects of approach [12].

Besides, the activities of teaching learning process used Brain Based Learning method in this research there is also activity of Lesson Study Learning Community, it can be created if there are two ways communication. In learning community the personnel involved can communicate each other. The student who involved in the activity may give information which is need by friend whom he talk to, as well as can ask information from his friend [13]. Lesson Study Learning Community was carried out collaboratively between teacher to plan, teach, see, revised (Plan Do-see) students and teachers as well as between students with a high level of care and all students can get attention [14]. The implementation of Lesson Study Learning Community also concerned on how the student study together (Collaboratively Learning) getting pay attention each other and no one is ignored and build a group of community of learning which is care of each other (caring community). In this activity there are two kinds of task which is given to the students, they are sharing task and jumping task. These task hopefully can build collaborative learning caring community [15].

In doing of Lesson Study Learning Community, one thing should be noticed is how the student learned together and no one was ignored. It's necessary to concern the student gesture or student body movement. The point which is analyzed is learning generally ( $\mathrm{U}$ model) as well as teacher's activity and the most important is collaborative learning activity in the group. It is designed so every the students can get the right of learning without exception and involved parents and the school institution. The objectives of learning community are the students able to study together, so and see, listen together includes the teacher does too. The whole aspects are the students learned some aspects, they are do working together or individually, speak up, ask, question/discussion and gather. Lesson Study Learning Community stressed on analyzing on how can the student can learn and collaborative it rather than on how the teachers mastery the material [16].

Based on Helen and Anne [17] reported that there was an increase in problems related to students' mental health that needed attention, one of which was because cultural differences and abilities between students made students not confident in expressing opinions and developing their abilities, so it needed the attention of teachers in the teaching and learning process, one of which is by adjusting the learning model that can increase students' self-confidence. In connection with the existing problems and the correlations that have been described, I conducted this research to find out how the learning process of the Brain Based Learning model based on Lesson Study Learning Community took place. The material chosen in this study is a sequence and series of numbers. This is because in determining the next number and getting the sum value in a certain sequence, students can use reasoning skills mathematically.

The following are some relevant research references in this study: (1) The Research of Erkan and Özlem [18] aimed to examine the effect of the Brain Based Learning model of attitudes and levels of learning motivation in students in natural science lessons on cell division and heredity. The results were using the Brain Based Learning model, the successful experimental group learning outcomes showed significant differences. The group that used the Brain Based Learning method got higher achievement scores than the control group. (2) The research of Rashida [19] aimed to determine the level of measure of awareness of knowledge, understanding, and classroom practice using the Brain Based Learning model in several schools in Mumbai, India. Several influencing factors such as gender, teacher faculty, teaching experience, and teacher education qualifications are used as a basic comparison. The results illustrate that the scale of the level of awareness of students who apply this learning model in the learning process does not show a significant difference to the independent variables. Only the teacher who teach science applied Brain Based Learning that make the brain worked harder and intend to the teacher who teach science will increase better. 


\section{METHODS}

The kind experiment that is used is mixed methods or methods that combine quantitative and qualitative methods. First step in this research is preparation of which areas should be observed, and coordinate with math teacher to decide the subject and the schedule of the research. Second step is making research instrument and earning instrument that will be validated by two validators. Result of validation will be counted to get the average totally for all aspects $(V a)$. The value of $V a$ is used to see the level of validity based on instrument validity by Hobri [20] which already modified

Table 1. Category of Instrument Validity Level

\begin{tabular}{|c|c|}
\hline Value of $V_{a}$ & Validity Level \\
\hline $2,5 \leq V_{a} \leq 3$ & Valid \\
\hline $1 \leq V_{a}<2,5$ & Invalid \\
\hline
\end{tabular}

using Normal test and $\mathrm{T}$ test. The next activity is interview by questioning to 4 students whom got different value in every class. The result of interview will be reducted based on the part of capability of student reasoning and finally it decided the conclusion.

\section{RESULTS AND DISSCUSSION}

This research is carried out by institution of SMA Negeri 5 Jember at the second semester in 2019/2020 with the population of XI MIPA. The pre test is given to the XI MIPA class. After that it has gotten the value of every class then it analyzed statistically with Normal tested which is provided in table 2 and Homogeneity tested provided in table 3 to get 2 sample classes.

Table 2. The results of the normality test of the pre-test values for the four classes

One-Sample Kolmogorov Test

\begin{tabular}{|l|l|c|c|c|c|}
\hline \multicolumn{2}{|c|}{} & XI MIPA 1 & XI MIPA 2 & XI MIPA 3 & XI MIPA 4 \\
\hline $\mathrm{N}$ & 31 & 31 & 31 & 30 \\
\hline \multirow{2}{*}{ Normal Parameters a,b } & Mean & 7.52 & 7.42 & 7.00 & 7.00 \\
\cline { 2 - 6 } & Std.Deviation & 1.895 & 2.029 & 1.880 & 1.438 \\
\hline \multirow{3}{*}{ Most Extreme Differences } & Absolute & .214 & .163 & .187 & .233 \\
\cline { 2 - 7 } & Positive & .143 & .163 & .187 & .233 \\
\cline { 2 - 7 } & Negative & -.214 & -.145 & -.154 & -.177 \\
\hline \multicolumn{2}{|l|}{ Kolmogorov -Smirnov Z } & 1.190 & .905 & 1.038 & 1.278 \\
\hline \multicolumn{2}{|l|}{ Asymp. Sig. (2-tailed) } & .118 & .386 & .231 & .076 \\
\hline
\end{tabular}

a. Test distribution is Normal.

b. Calculated from data.

The research instrument can be used if it has already met with the criteria of validity. If not then it will be revised and tested again until it achieved the value of criteria validity. The next step is concern the sample by giving a pie test for four classes, then it will be taken two classes homogeneity as a sample. After that analyze the result of pre test with normality test and homogeneity.

Both classes will apply the process of learning differently. The experiment class will apply process learning with method Brain Based Learning, while the control class will apply learning process mechanically. During the learning process, it will be observed to see the activity of students in joining step learning. Next it was given a test to know the capability in reasoning in mathematically thru post test. The value of the result post test from both classes will be compared whether to see and knowing if there are influences in learning process using Brain Based Learning based on lesson study Learning Community to the student's capability
Table 3. The results of the Homogeneity Test of the Pre-test Value of the Four Classes

\section{Test of Homogeneity of Variances}

\begin{tabular}{|c|c|c|c|}
\hline $\begin{array}{c}\text { Levene } \\
\text { Statistic }\end{array}$ & $\mathrm{df1}$ & $\mathrm{df2}$ & Sig. \\
\hline 1.402 & 3 & 119 & .246 \\
\hline
\end{tabular}

Based on the statistic analyse which is known showing that the four classes Normal and Homogen then the next step is chosen based on random sampling technic so it found the XI MIPA 1 as an experiment class and XI MIPA 2 as a control class. Furthermore, the nest activity is the experiment class will get a treatment of learning using Brain Based Learning based on Lesson Study Learning Community and the control class will be face learning mechanic.

The application of the Brain Base Learning based on Lesson Study Learning Community process in class XI MIPA 1 is carried out by collaborating with the stages 
of the Brain Based Learning model and Lesson Study Learning Community [9],[14]-[16]. It started with the step in arranging the formation of seat of the students changed into $\mathrm{U}$ shape, then it opened with greeting, praying and give the stimulation to the students that has been given previously such as games related to the material line and numeric. The step of initiation and acquisition, the students is grouped to get much information related to the material from many resources and it continued by doing some questions about sharing task. In phase incubation and posting memory, the students learned and comprehend again the material which is given by listening the music as relaxion. In elaborating phase the students present their result of their discussion in front of class while the other students noticed, asking and giving opinion. In verification step is done by giving some exercises "Jumping Task" to students who do the task individually as a homework and will be submitted for the next meeting. At the end of the meeting, the students should make a mind mapping as creatively as they can. In the last step is celebration and integration where both students who have a high score. During learning process, the observer observed the activities of students.

After the learning process have been done to both of classes, it given a post test for every classes to know whether there is an increment of result during the process as well. Based on the data the result of post test gained, and thru analyze statistically with normal test is provided in table 4 as well as $\mathrm{T}$ test provided in table 5 . class which is enough higher than the average of post test control class as seen on picture 1 . This result is appropriate with the previous one [18][19]. Whereas the result the class whom used the method of Brain Based Learning successively showed the different significant it is because of the group who applied the Brain Based Learning got high score than the control class.

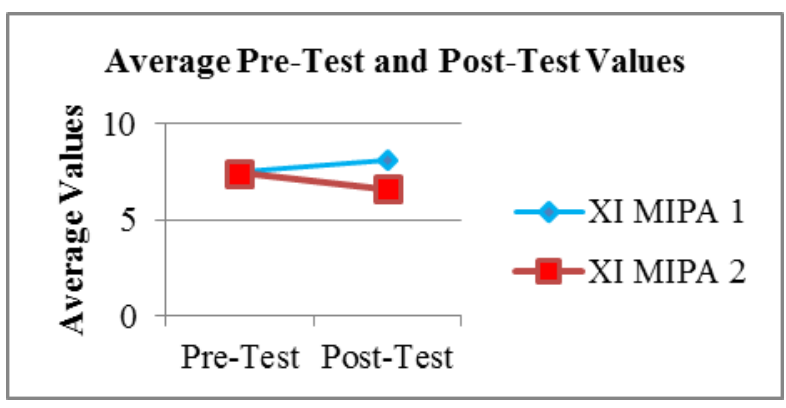

Figure 1. Graph of Change in Mean of Pre-Test and Post-Test Values

The result of Post Test of experiment class have upper score $12,67 \%$ than control class. The higher score of result learning is the same as level of reasoning capability of students. It's strong with the result of interview for some students who can answer and are able to explain, mastery of every problem/case that has been given, so the students must have an indicator in order to get the solution of every single problem. This appropriately with Brain Based Learning take a past, where as the students will be more actives, smart, and enjoyed the process of learning so the students are able

Table 4. The Results of Normality Test of Learming Student for Both Sample Classes

One-Sample Kolmogorov Test

\begin{tabular}{|l|l|c|c|}
\hline \multicolumn{2}{|l|}{} & XI MIPA 1 & XI MIPA 2 \\
\hline \multirow{2}{*}{ Normal Parameters ${ }^{\mathrm{a}, \mathrm{b}}$} & Mean & 31 & 31 \\
\cline { 2 - 4 } & Std.Deviation & 8.10 & 6.58 \\
\hline \multirow{3}{*}{ Most Extreme Differences } & Absolute & 1.904 & .822 \\
\cline { 2 - 4 } & Positive & .219 & .206 \\
\cline { 2 - 4 } & Negative & .219 & -.169 \\
\hline Kolmogorov -Smirnov Z & -.164 & 1.145 \\
\hline \multicolumn{2}{|l|}{ Asymp. Sig. (2-tailed) } & 1.222 & .145 \\
\hline
\end{tabular}

a. Test distribution is Normal.

b. Calculated from data.

Based on table 5 has known that significant value $0,002<0,05$ besides significant value the important value to the analysing are $\left.: 1) . \mathrm{T}_{\text {value }}=3,204 ; 2\right)$. $\mathrm{dk}=\mathrm{n}$ $2=62-2=60 ; 3) . \alpha=5 \%$. From $\mathrm{dk}$ is obtained value $\mathrm{T}_{\text {table }}=2000$. From the data is obtained the value $\mathrm{T}_{\text {table }}<$ $\mathrm{T}_{\text {value }}$ so $\mathrm{H}_{0}$ is refused $(\mu 1 \neq \mu 2)$. Besides data analysing is used $\mathrm{T}$ test the influence of model Brain Based Learning based on Lesson Study Learning Community can be seen from the average of post test experiment to develop their achievement [11].

Decrease of average value it is because of the Pre Test question is used to know the basic capability or just the result of student's. Moreover, it still provide the indicator reasoning capability of the students is shown is morely, on the other side with Post Test where the indicator is provided the reasoning capability of students in the higher level, so it can be tested in deeply. 
Table 5. The Results of T-Test Results on Post-Test Value.

\begin{tabular}{|c|c|c|c|c|c|c|c|c|c|c|}
\hline \multicolumn{11}{|c|}{ Independent Samples Test } \\
\hline & & \multicolumn{2}{|c|}{$\begin{array}{l}\text { Levene's Test } \\
\text { for Equality of } \\
\text { Variances }\end{array}$} & \multicolumn{7}{|c|}{ t-test for Equality of Means } \\
\hline & & \multirow[b]{2}{*}{$\mathrm{F}$} & \multirow[b]{2}{*}{ Sig. } & \multirow[b]{2}{*}{$\mathrm{T}$} & \multirow[b]{2}{*}{ df } & \multirow[b]{2}{*}{$\begin{array}{c}\text { Sig. } \\
(2- \\
\text { tailed })\end{array}$} & \multirow[b]{2}{*}{$\begin{array}{l}\text { Mean } \\
\text { Differen- } \\
\quad \text { ce }\end{array}$} & \multirow[b]{2}{*}{$\begin{array}{c}\text { Std. } \\
\text { Error } \\
\text { Differen- } \\
\text { ce }\end{array}$} & \multicolumn{2}{|c|}{$\begin{array}{l}95 \% \text { Confidence Interval } \\
\text { of the Difference }\end{array}$} \\
\hline & & & & & & & & & Lower & Upper \\
\hline \multirow[t]{2}{*}{ VALUE } & $\begin{array}{l}\text { Equal } \\
\text { variances } \\
\text { assumed }\end{array}$ & .014 & .905 & 3.204 & 60 & .002 & 1.516 & 473 & .570 & 2.463 \\
\hline & $\begin{array}{l}\text { Equal } \\
\text { variances } \\
\text { not } \\
\text { assumed }\end{array}$ & & & 3.204 & 59.884 & .002 & 1.516 & .473 & .570 & 2.463 \\
\hline
\end{tabular}

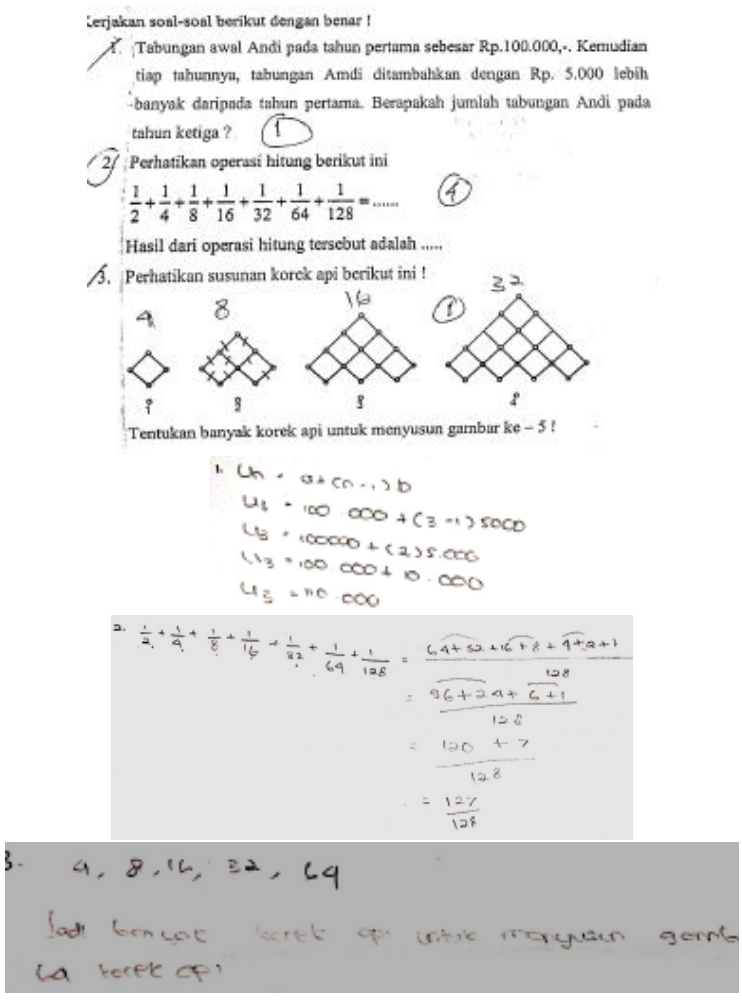

Figure 2. The Result of Student Sheet of Pre-Test

Based on the interview result, student explained how they are able to solve Post Test based on reasoning mathematically. In the group where brain based learning

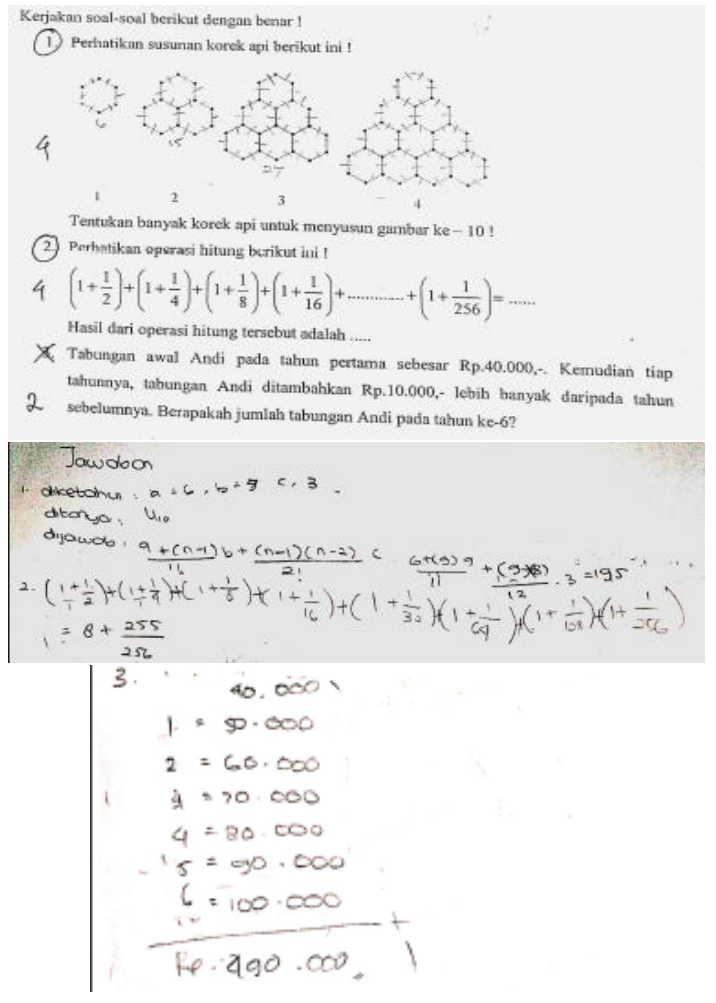

Figure 3. The Result of Student Sheet of Post-Test

based on Lesson Study Learning Community was applied students were in positive feelings during the lesson. Brain based learning has become a choice 
students participate happily. The activities conducted in the classroom have increased the student recognition of each other and working together. Varieties in method and techniques and classroom applications have provided affective lesson participation on terms of the students, is appropriately with the result of Serap and Melek's research [12] previously given and to know the level reasoning skill of the students and the students made mind mapping in comprehend the material given.

In this case, it's quite different with the situation in control class whereas some of the students still don't understand in material given, and prefer doing silent to not asking. Moreover, some students in this class are

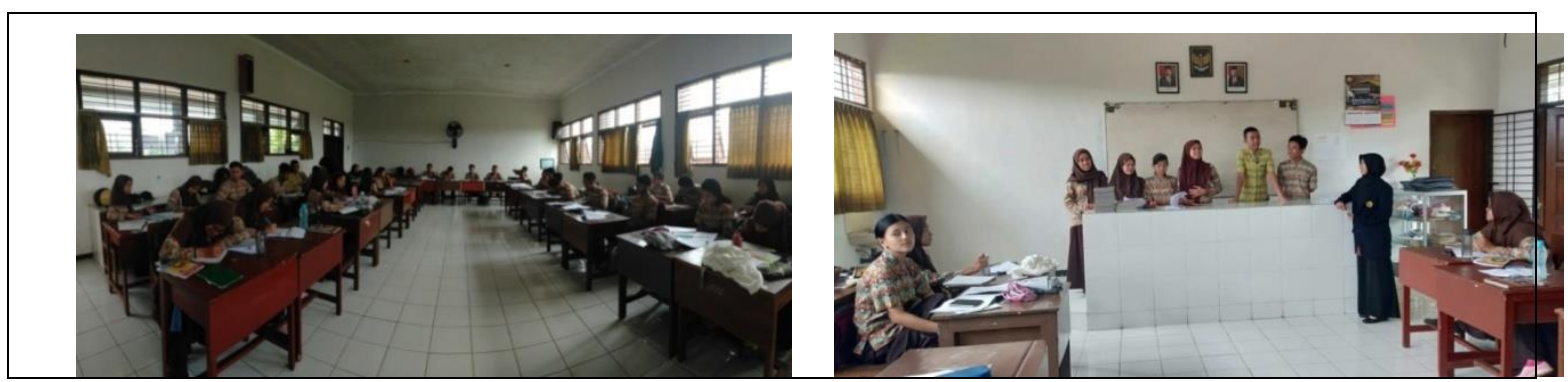

Figure 4. The Learning Process of Brain-Based Learning based on the Lesson Study Learning Community in the Experiment Class

The result of observation in experiment class showed that the interaction is happened more in two way direction whilst the students never feel doubt in interaction, they are discussing each other and work together to solve the problem. This activity is appropriate with the result of the experiment of Hobri [16]. It told that the learning of Lesson Study Learning Community is stressed on how the students study together and collaborate together so there is no students was ignored. The objectives in this learning method is the students are studying together listen each other includes the teacher should involved in group or individually to speak up, present the idea and asking the related material which discussed.

Several stages of the Brain Based Learning process can support and improve students' reasoning abilities. In the pre-presentation and preparation stages, the teacher provides a simple description and initial explanation of the material to be studied and gives students the opportunity to respond to what has been conveyed, so that the teacher provides a stimulus and students use simple reasoning skills to understand the initial description and explanation. In addition, at the elaboration stage students allow the opportunity to sort, investigate, analyse, test, and deepen their understanding of the material, and the teacher guides and directs the discussion so that the discussion process runs smoothly. At this stage the teacher guides students to understand the concept of the problem and its solution without using a fast pattern, and as well as the teacher explained the root and the condition of using fast pattern, so the students are adjusted to have reasoning skills even through they still use the fast pattern is solving their problem. In verification and desire checking stage, the teacher checked the level of students capability related to the material has been learned by giving some exercises a little bit higher that depended on the other students answer and ask to another student, they don't listen the teacher's explanation and instruction so that they feel doubt interacted with their teacher, and they prefer waiting, they are afraid of giving opinion. Their passive habitual made them scare in giving opinion, and doubtly to interact with their teacher.

\section{CONCLUSION}

Based on the result of the research and discussion explained above, it can be concluded that the positive influenced from model Brain Based Learning based on Lesson Study Learning Community to the reasoning capability of the students on the point discussion of line and numeric. These is supported with the result of $\mathrm{T}$ test on student Post Test value is obtained value $\mathrm{T}_{\text {table }}<\mathrm{T}_{\text {value }}$ with $\mathrm{T}_{\text {value }}=3,204$ and $\mathrm{T}_{\text {table }}=2000$, so $\mathrm{H}_{0}$ is refused $\mathrm{H}_{1}$ is accepted, as well as value of Pre Test and Post Test has shown that the average of the result learning in experiment class is increased rather than at control class. The increment of result learning is the same as increment of reasoning capability students. It's showed strongly that the result of interview for some student who are able to answer the question and explained them correctly it is because of the students used their reasoning capability met with capability in every indicator suitable with problem given and the students must have it in finding the solution.

In application of process learning Brain Based Learning based on Lesson Study Learning Community in class begins with arrange the formation of seat changed into $U$ shape. Then opening with greeting, praying, and give a stimulation of ice breaking, games with related to the sequences and series material, after giving such kind of game, the students are graped to do the sharing task. It continuo with giving jumping task to 
the students individually do as a homework and is submitted for the next meeting. And the end of meeting the students are given a task to make mind mapping with their own creatively. The process of this learning can be done step by step that encourage and increase the capability of reasoning of the students namely pre description, preparation, elaboration, and verification. A

\section{AUTHORS' CONTRIBUTIONS}

All authors contributed in collecting and analyzing the data in this article.

\section{ACKNOWLEDGMENTS}

This research was supported by Jember University. We thanks to SMAN 5 Jember for help us with parts of the data collection.

\section{REFERENCES}

[1] NCTM. Principles and Standards for School Mathematics United States of America: The National Council of Teachers of Mathematics, Inc., 2000.

[2] Sunardi. Hubungan antara Tingkat Penalaran Formal dan Tingkat Perkembangan Konsep Geometri Siswa Jurnal Ilmu Pendidikan 9(1), 2002, pp. 43-54.

[3] Pamungkas, A and Yuhana, Y. Pengembangan Bahan Ajar Untuk Peningkatan Kemampuan Penalaran Matematis Mahasiswa Calon Guru Matematika Jurnal Penelitian dan Pembelajaran Matematika 9(2), 2016, pp. 177-182.

[4] Zaman, A, Jumani, NB, Alamgir., Ali, A., Hussain, M A. Predictive Validity of Scores in Mathematics for Reasoning Ability in Mathematics for grade 9 Students in Khyber Pakhtunkhwa Based on Curriculum of Mathematics Procedia Social and Behavioral Sciences, (12), 2011, pp. 588-594.

[5] Siregar, N. Studi Perbandingan Kemampuan Penalaran Matematik Siswa Madrasah Tsanawiyah pada Kelas yang Belajar Geometri Berbantuan Geometer's Sketchpad dengan Siswa yang belajat Geometri tanpa Geometer's Sketchpad Tesis Bandung: PPS UPI, 2009.

[6] Arslan, C, Göcmencelebi, S. I., Tapan, M S. Learning and reasoning styles of pre service teachers': inductive or deductive reasoning on science and mathematics related to their learning style Procedia Social and Behavioral Sciences (1), 2009, pp. 2460-2465.

[7] Duman, B. The Effects of Brain-Based Learning on the Academic Achievement of Students with Different Learning Styles. Kuram ve Uygulamada Eğitim Bilimleri / Educational Sciences: Theory \& Practice, 10(4), 2010, pp. 2077-2103.
[8] Faidi, A. Tutorial Mengajar untuk Melejitkan Otak Kanan dan Kiri Anak Jogjakarta: DIVA Press, 2013.

[9] Jensen, E. Brain Based Learning California: Corwin Press, 2007.

[10] Haghighi, M. The effect of brain- based learning on Iranian EFL learner's achievement and retention Procedia - Social and Behavioral Sciences, (70), 2013, pp. 508 - 516.

[11] Yagcioglu, O. The advantages of brain based learning in ELT classes Procedia - Social and Behavioral Sciences, (152), 2014, pp. 258 - 262.

[12] Tüfekçial, Serap and Demirel, Melek. The effect of brain based learning on achievement, retention, attitude and learning process Elsevier publication, Procedia Social and Behavioral Sciences, 2009, pp. 1782-1791.

[13] Muchsin. Model Pengembangan Learning Community Dalam Pembelajaran Bahasa Inggris Terhadap Peningkatkan Prestasi Belajar Siswa Jurnal Pengembangan Masyarakat Islam, Ijtima 'iyya 9(1), 2016, pp. 71-92.

[14] Kusumawati, R, Hobri, Hadi, A.F. Implementation of Integrated Inquiry Collaborative Learning Based on the Lesson Study for Learning Community to Improve Student's Creative Thinking Skill Journal of Physics, 1211(1), 2019, pp. 012-097.

[15] Andini, S A, Susanto, \& Hobri. Students' Activity in Problem-Based Learning (PBL) Math Classroom Be Oriented Lesson Study For Learning Community (LSLC) International Journal of Advanced Research, 5(9), 2017, pp. 1395-1400.

[16] Hobri. Lesson Study for Learning Community: Review Hasil Short Term on Lesson Study V di Jepang Prosiding Seminar Nasional Pendidikan Matematika, Pamekasan, 2016, pp. 12-21.

[17] Mewett, H. F \& Sawyer, A M. International Students and Mental Health Journal of International Students Vol. 6(3), 2016, pp. 661677. ISSN: 2166-3750

[18] Akyürek ,Erkan and Afacan, Özlem. Effects Of Brain-Based Learning Approach On Students' Motivation And Attitudes Levels In Science Class Mevlana International Journal of Education (MIJE) Vol. 3(1), 2013, pp. 104-119.

[19] Kapadia,R H. Level of awareness about knowledge, belief and practice of brain based learning of school teachers in Greater Mumbai region Elsevier publication, Procedia Social and Behavioral Sciences, 2014, pp. 97-105.

[20]Hobri. Metodologi Penelitian Pengembangan (Aplikasi pada Penelitian Matematika) Jember: Pena Salsabila, 2010. 